\title{
Immunoglobulin D
}

\author{
Clyde Schultz* \\ Department of Biology, The University of Calgary, Alberta, Canada
}

\begin{abstract}
Immunoglobulin $\mathrm{D}$ is an ancient biological molecule which evolved and may cooperate functionally with Immunoglobulin M. It is expressed on B-lymphocytes and is secreted into the blood stream. It is produced as a monomeric antibody similar to Immunoglobulin $\mathrm{G}$, and has a half-life of less than 3 days. IgD is involved in various immune related functions including as a "replacement" in certain instances for IgM or IgA in individuals that may have deficiencies in one of these antibody classes.
\end{abstract}

\section{Introduction}

Immunoglobulin $\mathrm{D}$ (IgD or gamma $\mathrm{D}$ ) was discovered in the early 1960's (1). The antibody has a molecular weight of $185 \mathrm{kDa}$ and represents about $0.25 \%$ of the total amount of all immunoglobulins in the human serum [1]. IgD is thought to have a distant evolutionary history as it is associated with species that possess adaptive immune responses. The oldest of these are the certain species of cartilaginous fish which were present 500 million years ago [2]. This is at a juncture in evolutionary history when some of the first jawed vertebrates are thought to have appeared. The theory is that IgD has remained as is structurally and probably functionally since. $\operatorname{IgD}$ is expressed on B-lymphocytes as they leave the bone marrow as immature cells. As B-lymphocytes reach maturity, they will express both IgM and IgD [3]. IgD may have a role in allergic reactions as it may bind to both basophils and mast cells. These cell types have a common origin in the bone marrow but differentiate along slightly different pathways $[4,5]$. All these observations lead to the conclusion that IgD is at least partially a form of surveillance which is ancient in origin as it is positioned at sites of antigen entry into the mucosa.

\section{Structure}

IgD is found in serum at relatively low levels, about 30 micrograms/ $\mathrm{mL}$. The structure is similar to IgG and IgE. It is composed of two heavy and two light chains that are held together by di-sulfide bonds. IgD has a hinge region that intersects the FAB and FC region of the intact molecule and has a molecular weight of $\operatorname{IgD}$ is about $185 \mathrm{kDa}$. The disulfide bonds are relatively heat labile and are susceptible to proteases. $\mathrm{IgD}$ has a flexible locus to complement, and may act as a substitute in case of IgM defects [7]. B-lymphocytes may express IgD by alternative RNA splicing and class switching combinations. The latter occurs only in higher animals and leads to IgD diversification. IgD has an $\mathrm{H}$ region comprised of an amino terminal region with an influx of threonine and alanine residues. It also has $3 \mathrm{C}$ domains. The $\mathrm{C}$-terminal regions are rich in arginine and glutamate. These are modified by O-glycosylation for binding the $\mathrm{IgD}$ receptor onto $\mathrm{T}$-lymphocytes. The $\mathrm{H}$ regions of human IgD interact with heparin and associated proteoglycans which are expressed on basophils and mast cells, indicating a common origin [7].

\section{IgD function and clinical significance}

As mentioned, $\operatorname{IgD}$ exists in human (and other animal sera) at relatively low levels, the role it plays is specialized and is often in concert with cells, specifically at the surface. IgD may also circulate but not in abundance and this circulation appears to be localized. As part of the cell surface interaction function, IgD acts as a B-lymphocyte activation signal. B cells, when activated, produce specific antibody in response to an antigen. As part of the ballet which is the relationship between $\operatorname{IgD}$ and $\operatorname{IgM}$, IgM is solely expressed by non-activated or immature B lymphocytes, which means that normally IgM is expressed into maturity of an organism. When B lymphocytes leave the bone marrow where they are "born" IgD will begin to be expressed. When the B lymphocyte reaches maturity, it will express both antibody types, but with IgM predominating.

Circulating $\operatorname{IgD}$ is probably derived from a switch from $\operatorname{IgM}$ to $\operatorname{IgD}$ in the pharyngeal areas $[8,9]$. A significant function of secreted IgD appears to be in immunity of the upper respiratory track. Evidence suggests that in individuals deficient in either IgM or IgA, IgD levels are increased if either of these immunoglobulins are not in normal concentrations. It has been observed that IgA deficient patients with chronic upper respiratory infections will show an increase in IgD nasal plasma cells [10]. Further, patients exposed to respiratory pathogens such as rubella or Mycobacterium tuberculosis show an increase in serum $\operatorname{IgD}$. As mentioned above, $\operatorname{IgD}$ is rare in the spleen or intestine. However, it is more abundant in the tonsillar mucosa. These plasma cells may enter the circulatory system where they colonize other mucosal sites.

Secreted IgD, in addition to interactions with microbes directly via $\mathrm{V}$-specific on the antibody itself, establishes direct Fc interactions with mast cells, basophils and monocytes. In the case of basophils, this leads to the release of IL- 4 which can activate B-cells and thus IgG production [8]. However, that actual receptor has not as yet been identified [11].

IgD has the ability to activate certain pro-inflammatory functions in the immune system such as fever, antibiotic resistant inflammation (which may be systemic) and elevated serum IgD. These are some of the characteristics of hyper IgD syndrome, which is caused by substitutions of mevalonate kinase. Elevated IgD levels also cause periodic fever

${ }^{\star}$ Correspondence to: Clyde Schultz, Department of Biology, The University of Calgary, Alberta, Canada, Tel: 4032205278; E-mail: schultzc@ucalgary.ca

Key words: immunoglobulin, immunity, cell, humoral, antibody

Received: May 08, 2020; Accepted: May 26, 2020; Published: May 29, 2020 
aphthous stomatitis pharyngitis adenitis is another disease that has periodic fever coupled with aseptic mucosal inflammation. IgD armed basophils are present in the mucosa. While it is not clear what the pathogenesis of this syndrome is, it is clear that unfettered, IgD levels are associated with it $[8,12]$.

\section{References}

1. Rogentine GN Jr, Rowe DS, Bradley J, Waldmann TA, Fahey JL (1966) Metabolism of human immunoglobulin D. J Clin Investig 45: 1467-1478.

2. Ohta Y, Flajnik M (2006) IgD like IgM is a primordial immunoglobulin class perpetuated in most jawed vertebrates. PNAS 103: 10723-10728.

3. Übelhart R, Hug E, Bach MP, Wossning T, Dühren-von Minden M, et al. (2015) Responsiveness of B cells is regulated by the hinge region of IgD. Nat Immunol 16: 534-543.

4. Schatz DG, Ji Y (2011) Recombination centers and the orchestration of V9D0J recombination. Nature reviews Immunology 11: 251-263.

5. Gutzeit C, Chen K, Cerutti A (2018) The enigmatic function of IgD: some answers at last. Eur J Immunol 48: 1101-1113.
6. Preud'homme JL, Petit I, Barra A, Morel F, Lecron JC, et al. (2000) Structural and functional properties of membrane and secreted IgD. Mol Immunol 37: 871-887.

7. Swenson CD, Patel T, Parekh RB, Tamma SM, Coico RF, et al. (1998) Human T cell $\mathrm{IgD}$ receptors react with O-glycans on both human IgD and IgA1. Euro J Immunol 28 2366-2372.

8. Chen K, Xu W, Wilson M, He B, Miller NW, et al. (2009) Immunoglobulin D enhances immune surveillance by activating antimicrobial proinflammatory and B cell stimulating programs in basophils. Nat Immunol 10: 889-898.

9. Vladutiu A (2000) Immunoglobulin D. Properties, measurement, and clinical relevance. Clin Diagn Lab Immunol 7: 131-140.

10. Brandtzaeg P, Bjerke K, Kett K, Kvale D, Rognum TO, et al. (1987) Production and secretion of immunoglobulins in the gastrointestinal track. Ann Allergy 59: 21-39.

11. Denzel A, Maus UA, Gomez MR, Moll C, Niedermeier M, et al. (2008) Basophils enhance immunological memory responses. Nature Immunol 9: 733-742.

12. Rigante D, Capoluongo E, Bertoni B, Ansuini V, Chiaretti A, et al. (2007) First report of macrophage activation syndrome in hyperimmunoglobulinemia $\mathrm{D}$ with periodic fever syndrome. Arthritis Rheum 56: 658-661.

Copyright: $\odot 2020$ Schultz C. This is an open-access article distributed under the terms of the Creative Commons Attribution License, which permits unrestricted use, distribution, and reproduction in any medium, provided the original author and source are credited. 